\title{
Growth and biomass development of the introduced red alga Gracilaria vermiculophylla is unaffected by nutrient limitation and grazing
}

\author{
Lars Brammer Nejrup, Morten Foldager Pedersen* \\ Centre for Integrated Population Ecology (CIPE), Department of Environmental, Social and Spatial Change (ENSPAC), \\ Roskilde University, Denmark
}

\begin{abstract}
The invasive red alga Gracilaria vermiculophylla was first recorded in Denmark and Sweden in 2003 and has since been reported from several sites in Denmark, Sweden and northern Germany. The abundance of G. vermiculophylla is typically high at more eutrophic sites, whereas it remains relatively low at more oligotrophic sites. We recorded seasonal variations in growth and biomass development at 2 sites with contrasting nutrient status (eutrophic versus oligotrophic) to investigate whether nutrient limitation of growth and loss of biomass due to grazing from invertebrate herbivores could explain observed variations in biomass. The biomass of $G$. vermiculophylla at the eutrophic site (Holckenhavn Fjord) was ca. 300-fold larger than at the oligotrophic site (Fyns Hoved). Growth rates ranged from almost 0 in early spring to ca. $0.08 \mathrm{~d}^{-1}$ in mid-summer and did not vary among sites. The seasonal pattern of growth was correlated to insolation and water temperature, suggesting that nutrient availability played a minor role in controlling growth. Experimental nutrient enrichment confirmed these findings; nutrient enrichment enhanced the level of tissue nutrients, but only had a marginal effect on growth. Grazing losses were insignificant throughout the entire study period in both systems. Hence, site-specific variations in biomass could not be explained by differences in grazing pressure. Given the lack of support for nutrient limitation or herbivory to explain the observed variations of G. vermiculophylla biomass, we suggest that physical exposure caused by wind-driven waves may be the factor that controls biomass of $G$. vermiculophylla in these shallow estuaries.
\end{abstract}

KEY WORDS: Macroalgae · Invasive species · Nutrient limitation · Grazing Resale or republication not permitted without written consent of the publisher

\section{INTRODUCTION}

The red alga Gracilaria vermiculophylla (Ohmi) Papenfuss originates from Asia (Tseng \& Xia 1999) but has recently spread to North America and Europe (Bellorin et al. 2004, Rueness 2005, Freshwater et al. 2006, Thomsen et al. 2006, 2007). It was introduced to northern France with transplanted oysters intended for aquaculture (Mollet et al. 1998) and has since spread to Portugal in the south and Scandinavia in the north (Rueness 2005). G. vermiculophylla was first observed in Scandinavia in 2003 (Horsens Fjord, Denmark; Thomsen et al. 2006, Göteborg archipelago, Sweden; Nyberg et al. 2009) and has subsequently spread to several sites in Denmark, on the Swedish west coast and to the Baltic coast of northern Germany (Rueness 2005, Thomsen et al. 2007, Weinberger et al. 2008). G. vermiculophylla is commonly found in shallow, sheltered estuaries with soft sediment and relatively high nutrient levels (Thomsen et al. 2006). The abundance of $G$. vermiculophylla can be high, and it has become the dominant macroalga in several Danish estuaries where it has replaced fast-growing algae such as Ulva (including previous species of Enteromorpha) and Chaetomorpha (M. F. Pedersen pers. obs.), while in other cases, it has replaced more slow-growing benthic algae such as Fucus vesiculosus L. (e.g. Kiel Bight, Germany; Weinberger et al. 2008).

The fast spread of Gracilaria vermiculophylla and its potential effect on community composition in recipient 
systems has stimulated research on its ecological performance. A number of studies have investigated how environmental factors such as salinity, light and water temperature affect growth under laboratory conditions (e.g. Yokoya et al. 1999, Raikar et al. 2001). Yet, in situ growth and biomass development as well as the regulation of these parameters have received less attention (but see Thomsen \& McGlathery 2007, Weinberger et al. 2008, Thomsen et al. 2009)

Gracilaria vermiculophylla grows fast under optimal culture conditions (i.e. $0.1 \mathrm{~d}^{-1}$, Yokoya et al. 1999), but little is known about the seasonal variations in growth or the factors controlling that growth under field conditions. Weinberger et al. (2008) found that seasonal changes in the growth of G. vermiculophylla in Kiel Bight were closely correlated to insolation, water depth and temperature, but not to salinity, although the salinity in Kiel Bight is relatively low $(<16)$. These authors did not study the potential effect of nutrient availability on seasonality in growth, but fast-growing algae are typically more affected by nutrient limitation than more slow-growing species (Pedersen 1995, Pedersen \& Borum 1996, 1997, Pedersen et al. 2010). It is therefore possible that nutrient limitation may restrict growth and thus slow down the accumulation of G. vermiculophylla biomass at more nutrient-poor sites and/or during periods of low nutrient availability.

Gracilaria vermiculophylla has spread to several new sites in Denmark since it was first observed in Horsens Fjord in 2003. Yet, the subsequent development of biomass differs substantially among sites. In eutrophic sites, such as Holckenhavn Fjord, G. vermiculophylla has become very abundant, forming dense, drifting mats that cover large areas. At more nutrientpoor sites, it remains much less abundant. These sitespecific variations in nutrient availability may affect growth and, hence, the accumulation of biomass. Similarly, site-specific variations in grazing pressure may affect the rate at which standing biomass of the alga is lost from a site. Fast-growing algae are more susceptible to grazing losses than more slow-growing species (Cebrián \& Duarte 1994), because they tend to have a high nutritional value, less structural tissues and few morphological and chemical defences (Mattson 1980, Nicotri 1980, Duffy \& Hay 1990). Herbivory can control the abundance of fast-growing algae and affect algal community structure (e.g. Lubchenco 1978, GeertzHansen et al. 1993, Hauxwell et al. 1998), but the abundance of grazers and the potential grazing pressure may vary substantially among sites due to sitespecific variations in salinity and level of eutrophication. Low salinity, like that found in the inner portions of many estuaries, may lower the abundance of grazers, and eutrophication may have a similar effect. Hauxwell et al. (1998) showed that eutrophic sites dominated by drift algae had fewer invertebrate grazers and lower grazing pressure on macroalgae than more oligotrophic sites with a more diverse plant assemblage, likely because mats of drift algae create hypoxic conditions which affect the benthic fauna negatively (e.g. Norkko \& Bonsdorff 1996, Tagliapietra et al. 1998). Low biomass of $G$. vermiculophylla at oligotrophic sites may thus result from a combination of nutrient-limited growth and high grazing pressure, processes that are assumed to be less important at more eutrophic sites.

The aim of the present study was 2-fold: (1) to study seasonal patterns in in situ growth and biomass development of Gracilaria vermiculophylla in 2 contrasting (nutrient rich versus nutrient poor) estuaries to test for nutrient limitation effects on growth, and (2) to test whether site-specific variations in growth rate and invertebrate grazing could explain obvious differences in standing biomass. The study was carried out in 2 small, shallow estuaries on the island of Fynen, Denmark, from March to November 2008. The sites were assumed to differ with respect to nutrient loading and in the abundance of $G$. vermiculophylla. Holckenhavn Fjord is a eutrophic estuary with a very high abundance of G. vermiculophylla, while Fyns Hoved is a presumed oligotrophic inlet with a low abundance of G. vermiculophylla. We hypothesized that nutrient-limited growth and higher grazing pressure can explain the low biomass of $G$. vermiculophylla at the oligotrophic site.

\section{MATERIALS AND METHODS}

Study sites. Fyns Hoved is a shallow, semi-closed inlet $\left(55^{\circ} 36.9^{\prime} \mathrm{N}, 10^{\circ} 36.7^{\prime} \mathrm{E}\right)$ with an area of $1.1 \mathrm{~km}^{2}$ and a mean depth of less than $0.5 \mathrm{~m}$. The inlet connects to the Kattegat Sea through a narrow opening. The catchment is dominated by non-cultivated land, and no freshwater streams enter the inlet. The nutrient input to the inlet is presumed to be very low, being made up mainly of intruding water from the Kattegat. The sediment is made up of coarse sand with a relatively low organic content $(0.7 \pm 0.1 \%$ dry weight, DW). Seagrasses (Zostera marina L. and Ruppia maritima L.) are found in scattered patches, whereas attached Gracilaria vermiculophylla and Fucus vesiculosus dominate the macroalgal assemblage.

Holckenhavn Fjord is a small estuary $\left(55^{\circ} 17.8^{\prime} \mathrm{N}\right.$, $10^{\circ} 46.2^{\prime}$ E) covering $0.7 \mathrm{~km}^{2}$ and with a mean depth of $1.1 \mathrm{~m}$. Two streams enter the western most end of the estuary, which connects to Nyborg Fjord and the Belt Sea through a very narrow channel at the eastern end. The catchment area $\left(221 \mathrm{~km}^{2}\right)$ is dominated by agriculture, and the annual loading of $\mathrm{N}$ and $\mathrm{P}$ to the fjord is $452 \mathrm{t} \mathrm{N}$ and $9 \mathrm{t} \mathrm{P} \mathrm{yr}^{-1}$ (Regional Environmental Centre 
Fynen unpubl. data). Holckenhavn Fjord is among the most eutrophic estuaries in Denmark. The substrate is dominated by organically rich mud $(4.3 \pm 0.1 \% \mathrm{DW})$. Gracilaria vermiculophylla is the dominant macrophyte and is mainly found unattached, forming a dense mat which covers most of the bottom (M. F. Pedersen pers. obs.). Prior to the introduction of G. vermiculophylla, Holckenhavn Fjord was dominated by ephemeral macroalgae such as Chaetomorpha linum (OF Müller) Kützing and Ulva spp. (including species previously included in Enteromorpha), which are still found in low abundance.

Biomass. The biomass of Gracilaria vermiculophylla was surveyed in spring (April), summer (July) and fall (September) 2008. Surveys at Fyns Hoved, where the algal biomass was low and heterogeneously distributed, were conducted by placing 14 to 16 transects (each $40 \mathrm{~m}$ long) haphazardly across the inlet. Each transect was surveyed for G. vermiculophylla by moving a $1 \mathrm{~m}^{2}$ frame metre by metre along each transect. G. vermiculophylla occurring within the frame were collected and returned to the laboratory. In Holckenhavn Fjord, where the algal biomass was much higher and much more uniformly distributed across the estuary, 5 to 8 transects (each $40 \mathrm{~m}$ long) were placed haphazardly across the estuary. Biomass samples were collected for each $5 \mathrm{~m}$ along each transect using a smaller $0.25 \mathrm{~m}^{2}$ frame. Biomass samples were returned to the laboratory, rinsed and then dried to constant weight at $85^{\circ} \mathrm{C}$ to determine dry weight biomass.

Growth, nutrient limitation and grazing. In situ growth and the importance of nutrient limitation and grazing were examined monthly in both systems from March to October 2008. Healthy looking Gracilaria vermiculophylla was collected and cleaned of sediment, epiphytes and epifauna. Apical parts with several branches were weighted (blotted wet weight) and incubated in cylindrical transparent PVC incubation chambers $(10 \mathrm{~cm}$ in diameter and $20 \mathrm{~cm}$ long) that were closed at both ends with a net $(0.5 \mathrm{~mm}$ mesh size) that allowed water movement through the cylinders but prevented entry of grazers. The algae were randomly allocated to 1 of the following 3 treatments: (1) control (without added nutrients and with a net to exclude grazers), (2) +NP (with added nutrients and with nets to exclude grazers) and (3) +Grazers (without added nutrients and without a net at one end to allow entry of mobile grazers). Algae were fixed to a horizontally placed plate with silicon strings in each chamber. Nutrients were added to the +NP treatment chambers by leaving a net-tube filled with ca. $30 \mathrm{~g}$ slow-release fertiliser (PlataCore Depot 6M, Uranium Agrochem; total $\mathrm{N}=14 \%$, total $\mathrm{P}=4 \%$ ) in the chambers. The incubation chambers were finally mounted on a frame (3 chambers, 1 of each treatment, per frame), which was fixed to the sediment with stainless steel pegs at a water depth of 0.5 to $0.7 \mathrm{~m}$ outside existing algal mats. Five replicate frames were placed haphazardly with a distance of about 10 to $15 \mathrm{~m}$ between them at each study site. Nutrient addition enhances the concentrations of inorganic nutrients within the incubation chambers, but nutrient enrichment does not affect the nutrient content of algae in neighbouring incubation chambers placed more than 15 to $20 \mathrm{~cm}$ away (M. F. Pedersen unpubl.). The algae were left to grow for 5 to $15 \mathrm{~d}$ (depending on season) and were then collected, rinsed of sand and debris and weighed (blotted wet weight). Relative growth rates $(\mu)$ were calculated assuming exponential growth:

$$
\mu=\frac{\left(\ln \mathrm{FW}_{t}-\ln \mathrm{FW}_{0}\right)}{t}
$$

where $\mathrm{FW}_{\mathrm{t}}$ and $\mathrm{FW}_{0}$ are fresh weight biomass before and after the incubation, respectively, and $t$ is the incubation time in days. Grazing rates (g) were estimated as the difference between the mean growth rate obtained from the control treatments $\left(\mu_{C}\right)$ and growth rates obtained from the + Grazers treatment $\left(\mu_{\mathrm{G}}\right)$ :

$$
g=\bar{\mu}_{\mathrm{C}}-\mu_{\mathrm{G}}
$$

The incubated algae were finally dried to constant dry weight at $85^{\circ} \mathrm{C}$ together with 3 initial algal samples and stored for later analyses of tissue nutrients.

Environmental variables. Water temperature and light irradiance at the surface of the incubation chambers were recorded every 30 min during each incubation using HOBO loggers (Onset Computer Corporation) that were mounted on the frames carrying the incubation chambers. Readings from the loggers were transformed to photosynthetically active radiation (PAR) by calibration against an irradiance sensor (LiCor Li-190SA).

Light and temperature data were used to calculate daily light irradiance and average water temperature (per day) during each incubation period.

Three replicate water samples (each $250 \mathrm{ml}$ ) were collected at each site at the beginning and termination of all incubations. Salinity was measured in each water sample using a refractometer (ATAGO S/Mill) before samples were frozen at $-20^{\circ} \mathrm{C}$ for later analyses of dissolved inorganic nutrients (ammonium, nitrate, phosphorus). All water samples were GF/C-filtered prior to nutrient analysis. The concentrations of ammonium, nitrate and dissolved inorganic phosphorus were determined on duplicate sub-samples from each water sample using a QuickChem FIA 8000 autoanalyser (Zellweger Analysis ). Mean concentrations were estimated from the 3 replicate samples.

Tissue nutrients. Concentrations of tissue $\mathrm{C}$ and $\mathrm{N}$ in plants collected at the onset of each incubation (initial content) and in plants from the incubations (final sam- 
ples from the control and +NP treatments only) were determined on dried samples using an EA 1110 CHNS elemental analyser (CE instruments). Total tissue-P was determined on the same individuals after wet oxidation with boiling $\mathrm{H}_{2} \mathrm{SO}_{4}$ followed by spectrophotometric analysis (Strickland \& Parsons 1968). The concentration of $\mathrm{N}$ and $\mathrm{P}$ in algae was finally estimated as the mean between initial and final samples.

Statistical treatment. The effect of Treatment, Site and time (Month) on environmental variables (light, temperature, salinity and inorganic nutrients) and on Gracilaria vermiculophylla growth and tissue nutrients, and the effects of Site and Season (spring, summer, fall) on biomass of G. vermiculophylla were analysed using factorial analysis of variance (ANOVA) followed by Tukey's test for pairwise comparisons. Missing values appeared in all data sets (mostly due to lost observations), but especially in the data set for biomass because the number of transects surveyed intentionally differed among sites. Type III sum of squares, which are based on unweighted means and therefore not influenced by the sample size of each cell in the data set, was consequently used for all ANOVA analyses as recommended by Quinn \& Keough (2002). The factors treatment and site were considered fixed, while time (month or season) was considered a random factor (Underwood 1997). All data sets were ln-transformed prior to analysis to conform to the requirements for parametric analysis (i.e. normality of data and equal variances).

\section{RESULTS}

\section{Environmental variables}

Light at the surface of the incubation chambers was low in spring, increased during summer and decreased by late fall (Fig. 1, Table 1). Incident light on the chambers was significantly higher at Fyns Hoved than in Holckehavn Fjord. The significant interaction 'Month $\times$ Site' indicates that the seasonal variation in light differed among sites. Water temperature varied seasonally (Fig. 1, Table 1), with low temperatures $\left(5\right.$ to $\left.10^{\circ} \mathrm{C}\right)$ occurring in early spring and late fall and the highest temperatures $\left(18\right.$ to $\left.19^{\circ} \mathrm{C}\right)$ occurring in August. Water temperature did not vary among sites. Salinity varied significantly with time (Fig. 1, Table 1), but the variations did not follow a clear seasonal pattern. The mean salinity at Fyns Hoved (20 \pm 3 , range 16 to 25$)$ was significantly higher than that observed in Holckenhavn Fjord (14 \pm 3 , range 10 to 16$)$.

The concentration of dissolved inorganic nitrogen (DIN) varied seasonally and was higher in Holckenhavn Fjord than at Fyns Hoved, in spring and fall
(Fig. 1, Table 1). The mean concentration of DIN at Fyns Hoved was $2.3 \pm 2.2 \mu \mathrm{M}$, with the highest concentrations occurring in March $(3.4 \mu \mathrm{M})$ and October (7.2 $\mu \mathrm{M})$. Mean concentrations of DIN in Holckenhavn Fjord $(31.0 \pm 42.8 \mu \mathrm{M})$ were higher than at Fyns Hoved and varied from $<3 \mu \mathrm{M}$ in summer to $109.2 \mu \mathrm{M}$ in April. The significant interaction Month $\times$ Site shows that site-specific variations in DIN depended on time. The concentration of dissolved inorganic phosphorus (DIP) varied seasonally at both sites (Fig. 1, Table 1) and tended to increase during late summer and early fall. The mean concentration of DIP in Holckenhavn Fjord $(1.1 \pm 0.6 \mu \mathrm{M})$ was slightly higher than at Fyns Hoved $(0.6 \pm 0.5 \mu \mathrm{M})$, albeit not significantly so. The ratio between DIN and DIP varied seasonally at both sites (Fig. 1, Table 1). The mean DIN:DIP ratio in Holckenhavn Fjord $(74.8 \pm 86.9)$ was higher than that at Fyns Hoved $(14.9 \pm 11.7)$.

\section{Gracilaria biomass}

The biomass of Gracilaria vermiculophylla (Table 2) at Fyns Hoved was small, ranging from $0.4 \pm 0.7 \mathrm{~g} \mathrm{DW}$ $\mathrm{m}^{-2}$ in spring to $1.6 \pm 1.4 \mathrm{~g} \mathrm{DW} \mathrm{m}^{-2}$ in summer. The biomass in Holckenhavn Fjord was significantly higher than at Fyns Hoved (Tables 2 \& 3). The biomass in Holckenhavn Fjord peaked in spring $(464.4 \pm 426.3 \mathrm{~g}$ DW $\left.\mathrm{m}^{-2}\right)$ and reached the lowest level in fall $(176.4 \pm 65.4 \mathrm{~g}$ DW $\mathrm{m}^{-2}$ ). No significant seasonal (spring, summer, fall) difference was detected, nor a significant Season $\times$ Site interaction.

\section{Growth of Gracilaria}

Growth of Gracilaria vermiculophylla varied seasonally, with treatment, but not among sites (Fig. 2, Table 3). The significant interaction Month $\times$ Site suggests that the seasonal variation in growth differed between the 2 sites. Low rates were observed in March $\left(0.004 \pm 0.003 d^{-1}\right.$ at Fyns Hoved and $0.009 \pm 0.002 d^{-1}$ in Holckenhavn Fjord), while fast growth was observed at Fyns Hoved in June $\left(0.079 \pm 0.001 \mathrm{~d}^{-1}\right)$ and in Holckenhavn Fjord in July $\left(0.083 \pm 0.016 \mathrm{~d}^{-1}\right)$. Growth slowed down at both sites in fall.

Growth rate was affected by nutrient treatment, but not by grazing when compared across all sampling events (Table 3, Tukey's test: control vs. + NP, $p=0.025$, control vs. +Grazing, $\mathrm{p}=0.736$ ). When averaged across all sampling events, nutrient-enriched algae grew 15 and $18 \%$ faster than those from the control treatment at Fyns Hoved and in Holckenhavn Fjord, respectively, but no differences were significant when compared at individual sampling dates (Tukey's test, all p >0.05). 

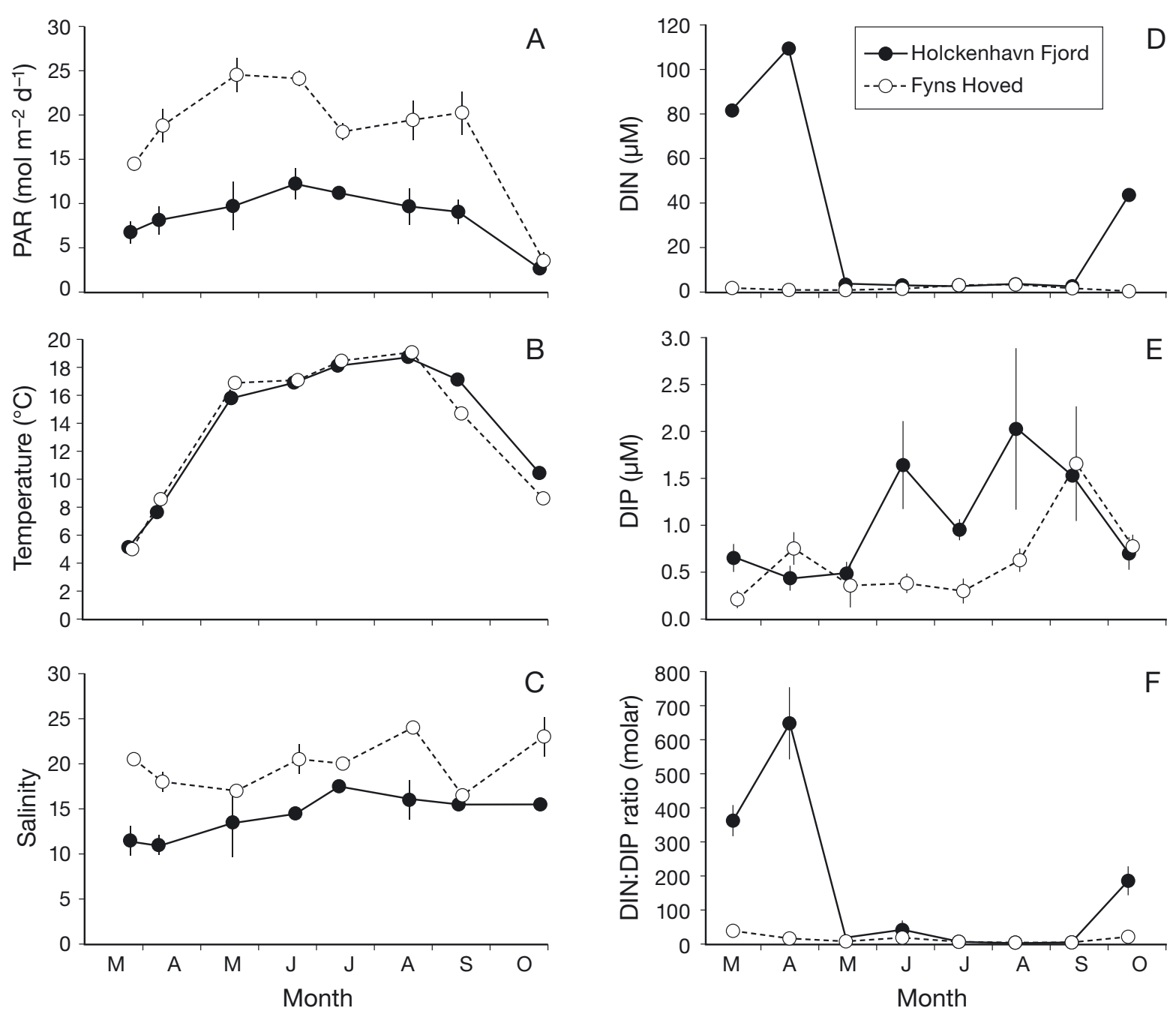

Fig. 1. Seasonal variation (mean $\pm \mathrm{SD}$ ) in average daily $(\mathrm{A})$ light availability (photosynthetically active radiation; PAR), (B) water temperature, (C) salinity, (D) concentrations of dissolved inorganic nitrogen (DIN $=\mathrm{NH}_{4}{ }^{+}+\mathrm{NO}_{3}{ }^{-}$), (E) dissolved inorganic phosphorus (DIP) and (F) the molar ratio between DIN and DIP at Fyns Hoved (O) and in Holckenhavn Fjord (๑) from March to

October 2008

We were unable to document any site-specific variation in the response to nutrient addition (Treatment $x$ Site: $F=1.58, \mathrm{p}=0.241$ ). Growth rates of algae exposed to grazers $\left(\mu_{\mathrm{G}}\right)$ were never significantly different from those of algae in the control treatment $\left(\mu_{\mathrm{C}}\right)$, and estimated grazing rates $(g)$ were never significantly different from 0 (Student's $t$-test, all $\mathrm{p}>0.05$ ). Grazing thus had no effect on growth rates.

\section{Tissue nutrients}

The C content of Gracilaria vermiculophylla averaged $32.6 \pm 1.9 \% \mathrm{C}$ of DW (across all treatments, sites and months) and was neither affected by the +NP treatment nor by site (data not shown). Month had a significant effect on $C$ content $(F=39.5$, p $<0.001)$, but this effect was caused by a single sample (September) where plants had a slightly lower content of $C$ than average $(29.2 \pm 0.7 \% \mathrm{C}$ of DW). Tissue $\mathrm{N}$ varied seasonally (Fig. 3, Table 4) and was higher in spring and late fall (3 to $3.5 \% \mathrm{~N}$ of DW) than in summer (ca. $1.5 \%$ $\mathrm{N}$ of DW). This pattern was more pronounced in Holckenhavn Fjord than at Fyns Hoved as indicated by the significant interaction Month $\times$ Site. Algae from the control treatment in Holckenhavn Fjord were richer in $\mathrm{N}$ than those from Fyns Hoved when averaged across all sampling events $(2.18 \pm 0.51$ versus $1.80 \pm 0.48 \% \mathrm{~N}$ in DW, $F=22.7, p=0.002)$. Algae from Holckenhavn Fjord were richer in $\mathrm{N}$ than those from Fyns Hoved in April, May, August, September and October (Tukey's test, $\mathrm{p}<0.05$ ). Nutrient enrichment caused a significant increase in tissue $\mathrm{N}$ (across all sampling events, Table 4), and algae from the +NP treatment were $11 \%$ 
Table 1. ANOVA for the effect of Site and Month on environmental variables (salinity, incident light on the incubation chambers, water temperature and dissolved inorganic nutrients) at Fyns Hoved and in Holckenhavn Fjord from March to October 2008. DIN, DIP: dissolved inorganic nitrogen and phosphorus, respectively

\begin{tabular}{|llcccc|}
\hline \multirow{2}{*}{ Response } & Factors & df & MS & $F$ & $\mathrm{p}$ \\
\hline Salinity & Site & 1 & 258.78 & 36.24 & 0.001 \\
& Month & 7 & 17.07 & 4.88 & 0.004 \\
& Site $\times$ Month & 7 & 7.14 & 2.04 & 0.113 \\
Light & Error & 16 & 3.50 & & \\
& Site & 1 & 1408.03 & 37.68 & $<0.001$ \\
& Month & 7 & 207.23 & 86.69 & $<0.001$ \\
& Site $\times$ Month & 7 & 37.37 & 15.63 & $<0.001$ \\
Water temperature & Error & 54 & 2.39 & & \\
& Site & 1 & 0.68 & 0.18 & 0.686 \\
& Month & 7 & 250.39 & 17897.30 & $<0.001$ \\
& Site $\times$ Month & 7 & 3.82 & 273.17 & $<0.001$ \\
DIN & Error & 59 & 0.01 & & \\
& Site & 1 & 21.00 & 5.50 & 0.057 \\
& Month & 6 & 8.44 & 15.08 & $<0.001$ \\
DIP & Site $\times$ Month & 6 & 3.82 & 6.82 & $<0.001$ \\
& Error & 54 & 0.60 & & \\
& Site & 1 & 0.86 & 3.60 & 0.107 \\
& Month & 6 & 0.41 & 3.48 & 0.004 \\
DIN:DIP & Site $\times$ Month & 6 & 0.24 & 2.10 & 0.075 \\
& Error & 72 & 0.12 & & \\
& Site & 1 & 20.80 & 3.25 & 0.121 \\
& Month & 6 & 11.59 & 8.07 & $<0.001$ \\
& Site $\times$ Month & 6 & 6.40 & 4.46 & 0.001 \\
& Error & 51 & 1.44 & & \\
\hline
\end{tabular}

Table 2. Gracilaria vermiculophylla. Dry weight biomass (mean \pm SD and range) at Fyns Hoved and in Holckenhavn Fjord across season. $(\mathrm{n}=$ no. of transects surveyed). DW: dry weight

\begin{tabular}{|llccc|}
\hline Site & Census & $\mathrm{n}$ & $\begin{array}{c}\text { Mean biomass } \\
\left(\mathrm{g} \mathrm{DW} \mathrm{m}^{-2}\right)\end{array}$ & $\begin{array}{c}\text { Range } \\
\left(\mathrm{g} \mathrm{DW} \mathrm{m}^{-2}\right)\end{array}$ \\
\hline Fyns Hoved & Spring & 15 & $0.4 \pm 0.7$ & $0-2.1$ \\
& Summer & 14 & $1.6 \pm 1.4$ & $0-3.4$ \\
& Fall & 15 & $0.9 \pm 1.3$ & $0-5.1$ \\
Holckenhavn Fjord & Spring & 6 & $464.4 \pm 426.3$ & $87.4-1075.7$ \\
& Summer & 8 & $299.8 \pm 156.6$ & $83.5-574.4$ \\
& Fall & 5 & $176.4 \pm 65.4$ & $98.1-233.7$ \\
\hline
\end{tabular}

Table 3. ANOVA for the effect of Site and Season on biomass and the effects of experimental treatment (control, + NP and +Grazers), Site and Month on growth of Gracilaria vermiculophylla at Fyns Hoved and in Holckenhavn Fjord from March to October 2008

\begin{tabular}{|llccrr|}
\hline Response & Factors & df & MS & $F$ & p \\
\hline Biomass & Site & 1 & 317.28 & 355.69 & 0.003 \\
& Season & 2 & 0.58 & 1.82 & 0.172 \\
& Site $\times$ Season & 2 & 0.89 & 2.78 & 0.071 \\
& Error & 57 & 0.33 & & \\
Growth rate & & & & \\
& Treatment & 2 & 0.00047 & 4.80 & 0.026 \\
& Site & 1 & 0.00033 & 0.16 & 0.699 \\
& Month & 7 & 0.00779 & 56.00 & $<0.001$ \\
& Treatment $\times$ Site & 2 & 0.00007 & 1.58 & 0.241 \\
& Treatment $\times$ Month & 14 & 0.00010 & 0.70 & 0.768 \\
Month $\times$ Site & 7 & 0.00201 & 14.47 & $<0.001$ \\
& Treatment $\times$ Month $\times$ Site & 14 & 0.00005 & 0.33 & 0.989 \\
& Error & 161 & 0.00014 & & \\
\hline
\end{tabular}

(Holckenhavn Fjord) and $7 \%$ (Fyns Hoved) richer in $\mathrm{N}$ than those from the control treatment. Differences were not significant when compared across treatment at individual sampling dates (Tukey's test, all p > 0.05). The P content in algae from Holckenhavn Fjord varied seasonally with high values in spring and late fall (0.3\% P in DW) and low in summer (ca $0.16 \% \mathrm{P}$ inDW). In contrast, the $\mathrm{P}$ content in algae from Fyns Hoved remained almost constant at $0.2 \% \mathrm{P}$ in DW throughout the study period (Fig. 3, Table 4). Algae from the control treatment in Holckenhavn Fjord were richer in $\mathrm{P}$ (mean $=0.24 \pm$ $0.05 \% \mathrm{P}$ in DW) than those from Fyns Hoved $(0.18 \pm 0.01 \% \mathrm{P}$ in DW) when compared across all sampling events. Time-specific differences occurred in March, April, September and October (Tukey's test, p < 0.05). Nutrient enrichment had a significant effect on the P content of G. vermiculophylla when compared across all sampling events $(F=39.3, \mathrm{p}=0.006)$. Plants from the +NP treatment contained 7 to $8 \%$ more $\mathrm{P}$ than those from the control treatment at both sites, but no differences were significant at individual sampling dates (Tukey's test, all $\mathrm{p}>0.05$ ). Tissue N:P ratios in plants from Fyns Hoved varied seasonally and were higher in spring (ca. 50) than in summer and fall (ca. 20). In contrast, the $\mathrm{N}: \mathrm{P}$ ratio in algae from Holckenhavn Fjord remained almost constant (ca. 21) throughout the study period. The overall mean N:P ratio in plants from the control treatment at Fyns Hoved $(27.1 \pm 11.0)$ was higher than in control algae from Holckenhavn Fjord (20.6 \pm 3.4$)$, and N:P ratios were unaffected by nutrient treatment $(26.5 \pm 10.3$ and $20.6 \pm 3.0$ at Fyns Hoved and in Holckenhavn Fjord, respectively).

\section{DISCUSSION}

This study shows that the biomass of Gracilaria vermiculophylla was ca. 300-fold higher in eutrophic Holckenhavn Fjord than in the more nutrientpoor Fyns Hoved, although G. vermicu- 


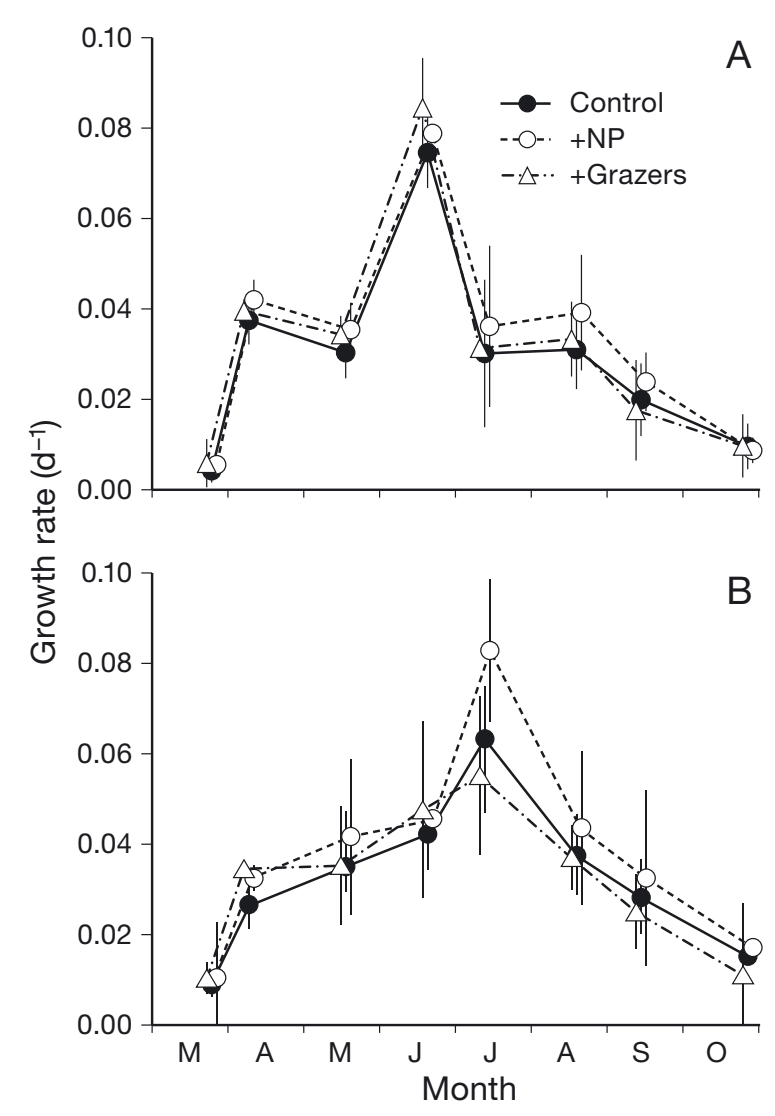

Fig. 2. Gracilaria vermiculophylla. Growth rates of plants from the 3 experimental treatments: control, $+\mathrm{NP}$ and +Grazers (A) at Fyns Hoved and (B) in Holckenhavn Fjord from March to October 2008. Data are mean $\pm \mathrm{SD}(\mathrm{n}=4$ or 5$)$

lophylla arrived in these systems at approximately the same time. The marked difference in biomass corresponds well to the general observation that G. vermiculophylla in Denmark are more abundant in relatively nutrient-rich sites. A similar distributional pattern has been reported for G. tikvahiae McLachlan in Waquoit Bay, Massachusetts, USA (Fox et al. 2008), suggesting that nutrient richness may affect the abundance of Gracilaria spp. Relatively fast-growing algae, such as G. vermiculophylla, should not only be more susceptible to nutrient limitation but also to grazing, than more slow-growing species (Cebrián \& Duarte 1994, Pedersen \& Borum 1996, Pedersen et al. 2010), so we expected that site-specific variations in both nutrient availability and grazing pressure could explain the obvious difference in biomass between the 2 study sites.

Gracilaria vermiculophylla grew fast during summer (0.07-0.08 $\mathrm{d}^{-1}$, corresponding to a doubling time of 8 to $10 \mathrm{~d}$ ), which is equal to in situ rates reported from Kiel Bight, Germany (Weinberger et al. 2008), and from Hog Island Bay, Virginia, USA (Thomsen \& McGlathery 2007). Growth rates were similar in Holckenhavn Fjord and Fyns Hoved, and the seasonal patterns of growth followed temporal changes in incident light and water temperature rather than variations in nutrient concentrations. This would either suggest that nutrients were equally available in the 2 systems (i.e. no difference in the degree and extent of nutrient limitation) or, alternatively, that the availability of nutrients differed among systems but was still high enough to ensure sufficient nutrient uptake and fast growth (i.e. no nutrient limitation) of $G$. vermiculophylla in both.

Nutrient richness was presumed to differ considerably between the sites, although we only had data for nutrient loading for one site (Holckenhavn Fjord). The catchment of Holckenhavn Fjord is relatively large and is dominated by agricultural areas. Nutrient loading is high, and Holckenhavn Fjord is one of the most eutrophic estuaries in Denmark. In contrast, the catchment of Fyns Hoved is small and dominated by uncultivated land and recreational areas. The contention that nutrient richness differed between the 2 systems was supported by much higher concentrations of inorganic nutrients, especially of DIN, in Holckenhavn Fjord during winter, spring and fall, whereas the concentrations in summer were equally low in both systems. Concentrations of inorganic nutrients may not necessarily be a good indicator of nutrient richness, as they reflect what is not taken up by the primary producers (Dodds 2003). However, the mean concentrations of DIN and DIP in Holckenhavn Fjord were 10 and 2 times higher, respectively, than at Fyns Hoved, while at the same time, the biomass of the dominant primary producer (Gracilaria vermiculophylla) was ca. 300 times higher in the former system. The presumed difference in nutrient richness between the 2 systems was further reflected by the fact that the $\mathrm{N}$ and $\mathrm{P}$ contents of algae from Holckenhavn Fjord were ca. $30 \%$ higher than those of algae from Fyns Hoved. The site-specific variation in standing stock of inorganic nutrients and the marked difference in algal $\mathrm{N}$ and $\mathrm{P}$ content together provide strong evidence that Holckenhavn Fjord is richer in nutrients than Fyns Hoved.

Low availability of nutrients (permanently at Fyns Hoved, periodically in both systems) should lead to nutrient-limited growth among faster-growing algae with high nutrient requirements and relatively low storage capacity (Pedersen \& Borum 1996, 1997, Pedersen et al. 2010). However, Gracilaria vermiculophylla grew at the same rate in the 2 systems, although the availability of inorganic nutrients differed substantially, and one would expect growth to be limited by nutrient shortage for a relatively long period at Fyns Hoved. This suggests that nutrient limitation was not at work, a suggestion that was supported by the fact that algae from both systems contained relatively high levels of tissue $\mathrm{N}$ and $\mathrm{P}$ throughout the summer. $\mathrm{N}$ and $\mathrm{P}$ concentrations in the algal tissues always remained 

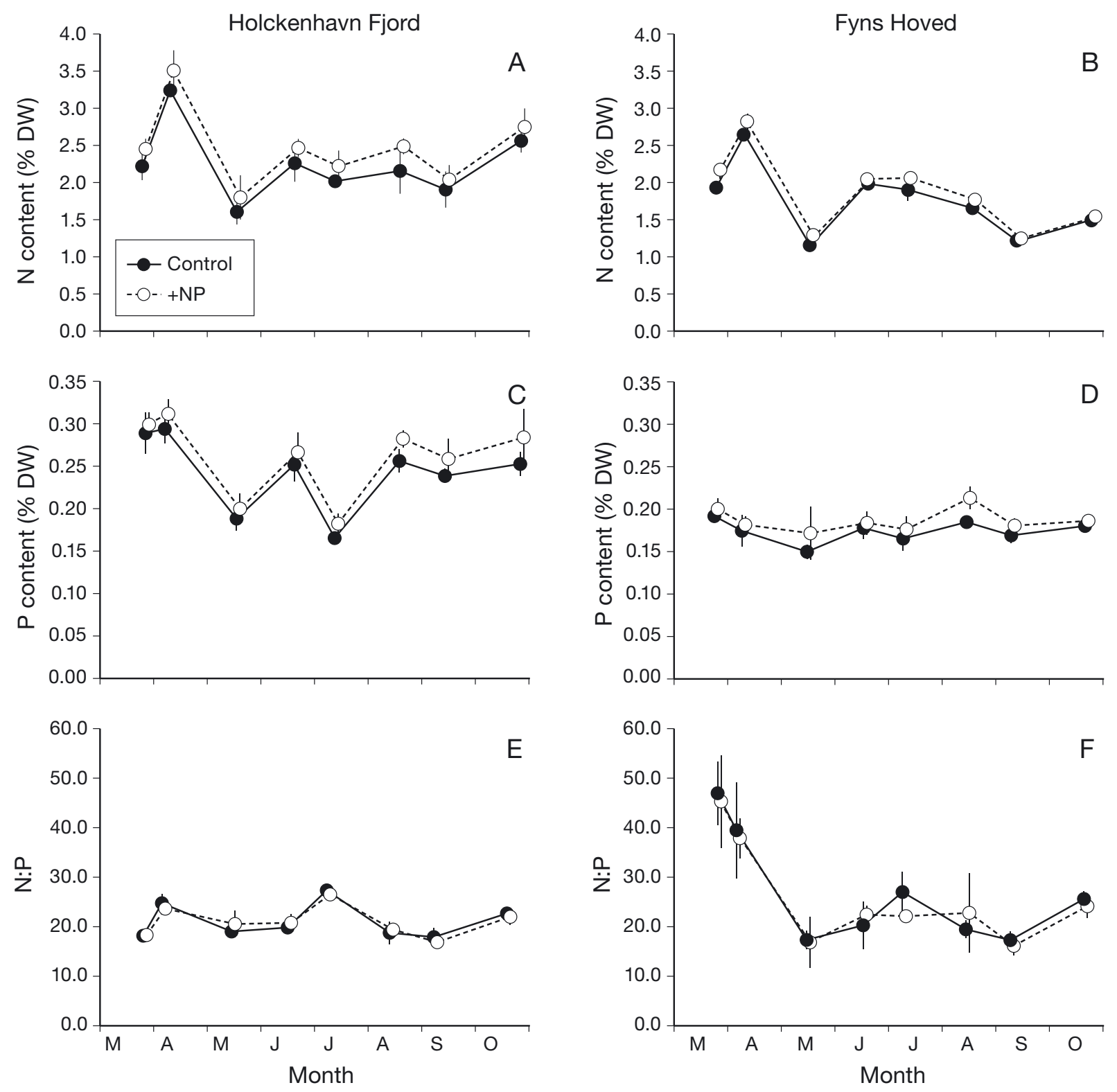

Fig. 3. Gracilaria vermiculophylla. $(\mathrm{A}, \mathrm{B}) \mathrm{N}$ content, $(\mathrm{C}, \mathrm{D}) \mathrm{P}$ content and $(\mathrm{E}, \mathrm{F})$ molar $\mathrm{N}$ :P ratios in algae from the control treatment and the $+N P$ treatment at Fyns Hoved and in Holckenhavn Fjord from March to October 2008. Data are mean \pm SD $(n=4$ or 5$)$

above levels expected to limit macroalgal growth (ca. 1.6 to $2.2 \% \mathrm{~N}$ in DW and 0.16 to $0.2 \% \mathrm{P}$ in DW; Duarte 1992, Pedersen \& Borum 1996, Pedersen et al. 2010). The low importance of nutrient limitation was further supported by the fact that experimental nutrient enrichment led to higher nutrient levels in the algae, while it only had a marginal effect on growth. Nutrient enrichment only raised the $\mathrm{N}$ and $\mathrm{P}$ content in algae by 7 to $11 \%$, but the absolute increase was much larger since the enriched algae also grew (15 to $18 \%$ ) faster than algae from the control treatment. The absolute enrichment was thus larger than indicated from differences in the relative content of $\mathrm{N}$ and $\mathrm{P}$ (i.e.\% of DW).
We therefore conclude that nutrient limitation had a marginal effect on the growth of $G$. vermiculophylla at both sites. Other studies have shown that the growth of Gracilaria is little affected by nutrient limitation; nutrient enrichment did not stimulate growth of G. vermiculophylla in Hog Island Bay, Virginia, in summer (Thomsen \& McGlathery 2007), and Teichberg et al. (2008) were unable to document nutrient limited growth of G. tikvahiae in Childs River and Sage Lot Pond, Massachusetts. In situ conditions and nutrient availability may well vary among these studies, but the results nevertheless indicate that members of the Gracilariales seem able to gain sufficient nutrients 
Table 4. Analysis of variance results for the effect of experimental treatment (control and +NP), site and month on the content of nitrogen, phosphorus and tissue N:P (molar) ratio in Gracilaria vermiculophylla at Fyns Hoved and in

\begin{tabular}{|c|c|c|c|c|c|}
\hline Response & Factors & $\mathrm{df}$ & MS & $F$ & $\mathrm{p}$ \\
\hline \multirow[t]{8}{*}{$\mathrm{N}$ content } & Treatment & 1 & 1.24 & 123.96 & $<0.001$ \\
\hline & Site & 1 & 9.52 & 22.67 & 0.002 \\
\hline & Month & 7 & 4.06 & 170.91 & $<0.001$ \\
\hline & Treatment $\times$ Site & 1 & 0.13 & 13.23 & 0.008 \\
\hline & Treatment $\times$ Month & 7 & 0.01 & 0.41 & 0.896 \\
\hline & Site $\times$ Month & 7 & 0.42 & 17.71 & $<0.001$ \\
\hline & Treatment $\times$ Site $\times$ Month & 7 & 0.01 & 0.44 & 0.876 \\
\hline & Error & 112 & 0.02 & & \\
\hline \multirow[t]{8}{*}{ P content } & Treatment & 1 & 0.0079 & 39.28 & $<0.001$ \\
\hline & Site & 1 & 0.2919 & 14.74 & 0.006 \\
\hline & Month & 7 & 0.0120 & 15.56 & $<0.001$ \\
\hline & Treatment $\times$ Site & 1 & 0.0007 & 2.29 & 0.174 \\
\hline & Treatment $\times$ Month & 7 & 0.0002 & 0.28 & 0.961 \\
\hline & Site $\times$ Month & 7 & 0.0198 & 25.59 & $<0.001$ \\
\hline & Treatment $\times$ Site $\times$ Month & 7 & 0.0003 & 0.52 & 0.818 \\
\hline & Error & 121 & 0.0008 & & \\
\hline \multirow[t]{8}{*}{$\mathrm{N}: \mathrm{P}$} & Treatment & 1 & 0.08 & 0.01 & 0.930 \\
\hline & Site & 1 & 1104.10 & 2.09 & 0.191 \\
\hline & Month & 7 & 565.74 & 39.36 & $<0.001$ \\
\hline & Treatment $\times$ Site & 1 & 2.7 & 0.83 & 0.393 \\
\hline & Treatment $\times$ Month & 7 & 9.75 & 0.68 & 0.690 \\
\hline & Site $\times$ Month & 7 & 527.13 & 36.68 & $<0.001$ \\
\hline & Treatment $\times$ Site $\times$ Month & 7 & 3.34 & 0.23 & 0.977 \\
\hline & Error & 107 & 14.37 & & \\
\hline
\end{tabular}
Holckenhavn Fjord from March to October 2008

variation in biomass across sites could therefore not be explained by site-specific variations in growth caused by nutrient limitation.

Standing biomass is not only determined by the rate at which new biomass is produced, but also by the rate at which biomass is lost. Herbivory can constitute an important loss factor for plants, and invertebrate grazers can reduce algal biomass and affect the composition of algal assemblages (e.g. Lubchenco 1978, Geertz-Hansen et al. 1993, Hauxwell et al. 1998, Duffy \& Hay 2000). We were nevertheless unable to document any significant grazing losses on Gracilaria vermiculophylla in the present investigation. We initially expected that the abundance of grazers, and thus the grazing pressure, would be low in eutrophic Holckenhavn Fjord because the abundance of grazers often correlates negatively to nutrient richness (Hauxwell et al. 1998) due to a higher frequency of hypoxia at more eutrophic sites (e.g. Norkko \& Bonsdorff 1996, Fox et al. 2009). The abundance of grazers was not quantified in this study, but many grazers (amphipods, isopods and snails) were found hiding in the algae

even at low substrate concentrations. Gracilaria may thus have a high affinity for inorganic nutrients, organic nutrients may serve as additional nutrient sources (Tyler et al. 2005), and/or it may have a large storage capacity for nutrients.

The storage capacity of Gracilaria vermiculophylla should potentially be larger than that of true fastgrowing algae (i.e. uniseriate filamentous or foliose species being 1 to 2 cell layers thick) because G. vermiculophylla is thicker and grows at lower rates. On the other hand, the growth rate of $G$. vermiculophylla reached $0.08 \mathrm{~d}^{-1}$ in mid-summer, corresponding to a doubling time of ca. $7.5 \mathrm{~d}$. This means that the tissue concentrations of $\mathrm{N}$ and $\mathrm{P}$ would be reduced by $50 \%$ and get below the threshold considered limiting for algal growth within $1 \mathrm{wk}$ if the concentrations of dissolved nutrients were low enough to prevent G. vermiculophylla to acquire any external nutrients. A storage capacity of $7.5 \mathrm{~d}$ is still rather short compared to that of other algae (Pedersen \& Borum 1996, Pedersen et al. 2010), and cannot explain why $G$. vermiculophylla remained unaffected by nutrient limitation throughout summer. Whatever the reason, nutrient limitation had very little impact on in situ growth of $G$. vermiculophylla, and the observed sampled for the biomass survey and in the open cages used for the grazer treatment at both sites (see also Nyberg et al. 2009). Typical grazers were thus abundant at both sites, but grazing rates were always small and never significantly different from 0 . Weinberger et al. (2008) found that common grazers from Kiel Bight and preferred Fucus vesiculosus to G. vermiculophylla in 2-choice feeding trials. Vinzent (2009) obtained similar results in laboratory feeding studies where Idotea baltica, Gammarus sp. and Littorina littorea preferred fast-growing macroalgae (Ulva sp. and Ceramium virgatulum Roth, formerly C. rubrum) to G. vermiculophylla and $F$. vesiculosus when given a choice, although these herbivores would consume and survive on G. vermiculophylla when they did not have a choice. However, feeding rates were low when G. vermiculophylla was offered alone, and the herbivores grew less well than when fed with other algae (Vinzent 2009). The low preference for G. vermiculophylla observed in these culture and field studies may be due to morphological, nutritional or chemical cues that prevent or reduce herbivory (Duffy \& Hay 1990), although the exact mechanisms in this case remain unknown. consumed little G. vermiculophylla in no-choice trials 
The marked difference in Gracilaria biomass between the 2 study sites could not be explained by sitespecific variations in growth, nor by differences in grazer-mediated biomass losses. This result was quite surprising, but it may nevertheless add to explain why G. vermiculophylla is such a strong invader. Proliferation of fast-growing macroalgae is often restricted by a combination of nutrient limitation and grazing (e.g. Geertz-Hansen et al. 1993), but G. vermiculophylla seemed completely unaffected by these processes even when nutrient concentrations were low and the potential grazing pressure was high (i.e. at Fyns Hoved).

Which mechanisms are then causing the observed site-specific variations in biomass of Gracilaria vermiculophylla if nutrient richness and grazing pressure are unimportant? Holckenhavn Fjord and Fyns Hoved do not only differ in nutrient richness, but also with respect to exposure to winds and mean depth. Holckenhavn Fjord is surrounded by hills to the north, west and south and is therefore relatively protected against winds. In contrast, Fyns Hoved is surrounded by low land (a few metres above sea level), making it much more susceptible to wind exposure than Holckenhavn Fjord. Further, the mean water depth at Fyns Hoved is only half that in Holckenhavn Fjord. The effect of higher wind exposure combined with more shallow waters at Fyns Hoved leave benthic organisms subject to higher levels of wave exposure and water movement than in Holckenhavn Fjord. Water movement may have a dramatic effect on the biomass of drift macroalgae, which may be exported to deeper waters or become washed upon the shore (Flindt et al. 1997, Salomonsen et al. 1997). For example, Salomonsen et al. (1999) showed that advective transport of Ulva lactuca due to currents and wind-driven water movement caused a higher loss of biomass than grazing, which is otherwise considered a significant loss process for Ulva in many shallow systems. We find it very likely that the physical stress imposed by wind and waves at Fyns Hoved is strong enough to detach attached specimens of $G$. vermiculophylla and remove them from the system and that site-specific variations in physical stress therefore may explain observed variations in biomass of G. vermiculophylla. Variations in wind regime and morphometry may, to some extent, also explain the observed variation in the abundance of G. vermiculophylla among other Danish estuaries. Systems with a high biomass of Gracilaria are not only richer in nutrients than systems of low biomass, but they also tend to be more sheltered (having a lower fetch and higher depth) and have more narrow connections to the neighbouring sea (i.e. lower water exchange) than areas with a relatively low abundance. At present, we have no estimates of the amount of $G$. vermiculophylla that are exported and/or washed up on the shores in different systems, and future studies should be conducted to test this possibility and quantify its potential importance.

Acknowledgements. L.B.N. was supported by grant no. 27205-0161 (CIPE) and M.F.P. by grant no. 272-08-0577 (MARINVA) from the Danish Natural Sciences Research Council. We thank M. S. Thomsen and 3 anonymous referees for valuable discussions and constructive criticism of an early version of the manuscript.

\section{LITERATURE CITED}

Bellorin AM, Oliveirsa MC, Oliveira EC (2004) Gracilaria vermiculophylla: a western Pacific species of Gracilariaceae (Rhodophyta) first recorded from the eastern Pacific. Phycol Res 52:69-79

> Cebrián J, Duarte CM (1994) The dependence of herbivory on growth rate in natural plant communities. Funct Ecol 8: $518-525$

> Dodds WK (2003) Misuse of inorganic N and soluble reactive $\mathrm{P}$ concentrations to indicate nutrient status of surface waters. J N Am Benthol Soc 22:171-181

Duarte CM (1992) Nutrient concentrations of aquatic plants: patterns across species. Limnol Oceanogr 37:882-889

Duffy JE, Hay ME (1990) Seaweed adaptations to herbivory - chemical, structural, and morphological defenses are often adjusted to spatial or temporal patterns of attack. Bioscience 40:368-375

> Duffy JE, Hay ME (2000) Strong impacts of grazing amphipods on the organization of a benthic community. Ecol Monogr 70:237-263

Flindt M, Salomonsen J, Carrer M, Bocci M, Kamp-Nielsen L (1997) Loss, growth and transport dynamics of Chaetomorpha aerea and Ulva rigida in the Lagoon of Venice during an early summer field campaign. Ecol Model 102: 133-141

Fox SE, Stieve E, Valiela I, Hauxwell J, McClelland J (2008) Macrophyte abundance in Waquoit Bay: effects of landderived nitrogen loads on seasonal and multi-year biomass patterns. Estuar Coast 31:532-541

Fox SE, Teichberg M, Olsen YS, Heffner L, Valiela I (2009) Restructuring of benthic communities in eutrophic estuaries: lower abundance of prey leads to trophic shifts from omnivory to grazing. Mar Ecol Prog Ser 380:43-57

> Freshwater DW, Montgomery F, Green JK, Hammer RM, Williams M, Whitfield PE (2006) Distribution and identification of an invasive Gracilaria species that is hampering commercial fishing operations in southeastern North Carolina, USA. Biol Invasions 8:631-637

Geertz-Hansen O, Sand-Jensen K, Hansen DF, Christiansen A (1993) Growth and grazing control of abundance of the marine macroalga, Ulva lactuca L. in a eutrophic Danish estuary. Aquat Bot 46:101-109

> Hauxwell J, McClelland J, Behr PJ, Valiela I (1998) Relative importance of grazing and nutrient controls of macroalgal biomass in three temperate shallow estuaries. Estuaries 21:347-360 doi:10.2307/1352481

> Lubchenco J (1978) Plant species diversity in a marine intertidal community: importance of herbivore food preference and algal competitive abilities. Am Nat 112:23-39

> Mattson WJ (1980) Herbivory in relation to plant nitrogen content. Annu Rev Ecol Syst 11:119-161

> Mollet JC, Rahaoui A, Lemoine Y (1998) Yield, chemical composition and gel strength of agarocolloids of Gracilaria 
gracilis, Gracilariopsis longissima and the newly reported Gracilaria cf. vermiculophylla from Roscoff (Brittany, France). J Appl Phycol 10:59-66

Nicotri ME (1980) Factors involved in herbivore food preference. J Exp Mar Biol Ecol 42:13-26

Norkko A, Bonsdorff E (1996) Rapid zoobenthic community responses to accumulations of drifting algae. Mar Ecol Prog Ser 131:143-157

Nyberg CD, Thomsen MS, Wallentinus I (2009) Flora and fauna associated with the introduced red alga Gracilaria vermiculophylla. Eur J Phycol 44:395-403

Pedersen MF (1995) Nitrogen limitation of photosynthesis and growth across aquatic plant communities in a Danish estuary (Roskilde Fjord). Ophelia 41:261-272

Pedersen MF, Borum J (1996) Nutrient control of algal growth in estuarine waters. Nutrient limitation and the importance of nitrogen requirements and nitrogen storage among phytoplankton and species of macroalgae. Mar Ecol Prog Ser 142:261-272

Pedersen MF, Borum J (1997) Nutrient control of estuarine macroalgae: growth strategy and the balance between nitrogen requirements and uptake. Mar Ecol Prog Ser 161: 155-163

Pedersen MF, Borum J, Fotel FL (2010) Phosphorus dynamics and limitation of fast- and slow-growing temperate seaweeds in Oslofjord, Norway. Mar Ecol Prog Ser 399: 103-115

Quinn GP, Keough MJ (2002) Experimental design and data analysis for biologists. Cambridge University Press, Cambridge

Raikar SV, Iima M, Fujita Y (2001) Effect of temperature, salinity and light intensity on the growth of Gracilaria spp. (Gracilariales, Rhodophyta) from Japan, Malaysia and India. Indian J Mar Sci 30:98-104

Rueness J (2005) Life history and molecular sequences of Gracilaria vermiculophylla (Gracilariales, Rhodophyta), a new introduction to European waters. Phycologia 44:120-128

Salomonsen J, Flindt MR, Geertz-Hansen O (1997) Significance of advective transport of Ulva lactuca for a biomass budget on a shallow water location. Ecol Model 102: 129-132

Salomonsen J, Flindt M, Geertz-Hansen O, Johansen C (1999) Modelling advective transport of Ulva lactuca (L) in the sheltered bay, Mollekrogen, Roskilde Fjord, Denmark. Hydrobiologia 397:241-252

Strickland JD, Parsons TR (1968) A practical handbook of seawater analysis. Bull Res Board Can No 167

Tagliapietra D, Pavan M, Wagner C (1998) Macrobenthic

Editorial responsibility: Hans Heinrich Janssen, Oldendorf/Luhe, Germany community changes related to eutrophication in Palude della Rosa (Venetian Lagoon, Italy). Estuar Coast Shelf Sci 47:217-226

Teichberg M, Fox SE, Aguila C, Olsen YS, Valiela I (2008) Macroalgal responses to experimental nutrient enrichment in shallow coastal waters: growth, internal nutrient pools, and isotopic signatures. Mar Ecol Prog Ser 368: $117-126$

Thomsen MS, McGlathery KJ (2007) Stress tolerance of the invasive macroalgae Codium fragile and Gracilaria vermiculophylla in a soft-bottom turbid lagoon. Biol Invasions 9:499-513

Thomsen MS, Gurgel CFD, Fredericq S, McGlathery KJ (2006) Gracilaria vermiculophylla (Rhodophyta, Gracilariales) in Hog Island Bay, Virginia: a cryptic alien and invasive macroalga and taxonomic correction. J Phycol 42: 139-141

Thomsen MS, Staehr PA, Nyberg CD, Schwærter D, KrauseJensen D, Silliman BR (2007) Gracilaria vermiculophylla (Ohmi) Papenfuss, 1967 (Rhodophyta, Gracilariaceae) in Northern Europe, with emphasis on Danish conditions, and what to expect in the future. Aquat Invasions 2:83-94

> Thomsen MS, McGlathery KJ, Schwartschild A, Silliman BR (2009) Distribution and ecological role of the non-native macroalga Gracilaria vermiculophylla in Virginia salt marshes. Biol Invasions 11:2303-2316

> Tseng CK, Xia BM (1999) On the Gracilaria in the western Pacific and the southeastern Asia region. Bot Mar 42: 209-217

- Tyler AC, McGlathery KJ, Macko SA (2005) Uptake of urea and amino acids by the macroalgae Ulva lactuca (Chlorophyta) and Gracilaria vermiculophylla (Rhodophyta). Mar Ecol Prog Ser 294:161-172

Underwood AJ (1997) Experiments in ecology: their logical design and interpretation using analysis of variance. Cambridge University Press, Cambridge

Vinzent J (2009) Feeding preference and performance of three meso-grazers fed with the invasive macroalga Gracilaria vermiculophylla and three naturally occurring macroalgae. MSc thesis, University of Roskilde

> Weinberger F, Buchholz B, Karez R, Wahl M (2008) The invasive red alga Gracilaria vermiculophylla in the Baltic Sea: adaptation to brackish water may compensate for light limitation. Aquat Biol 3:251-264

- Yokoya NS, Kakita H, Obika H, Kitamura T (1999) Effects of environmental factors and plant growth regulators on growth of the red alga Gracilaria vermiculophylla from Shikoku Island, Japan. Hydrobiologia 399:339-347

Submitted: February 18, 2010; Accepted: August 5, 2010 Proofs received from author(s): September 23, 2010 